\title{
口腔粘膜疾急に対する炭酸カスレーザーの危用
}

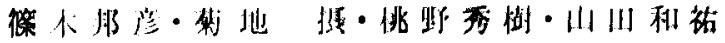 \\ 㜣田靖・林谁此
}

\section{Application of carbon dioxide laser to treat the superficial lesions of oral mucosa}

\author{
Kunihiko Sinnok1 - Selsu KıkUc11 - Jideki MOMONo \\ Kazumasa YAMADA - Yasushi Fujita - Susumu Hayasil
}

\begin{abstract}
The carbon dioxide laser has many advantageous characteristics. The edge of a laser irradiated wound is covered by only a thin layer of ner rotic substances. Moreover, the irradiation is made without any physical damage to the romaining tissuc.

So if we can vaporize the superficial tissue of mucosal lesions, we will be able to treat leukoplakia, papilloma, and lichen planus.

Before clinical application, we examined dog's tongue bealing after defocused carbon dioxide laser irradiation. The irradiated tissues were dissected in order to examine by light and scanning electron microscopes with spot size $5 \mathrm{~mm}$ and output power $10 \sim 20 \mathrm{~W}$. We irradiated the lesions of leukoplakia, papilloma and lichen planus. As a result we think the carbon dioxide laser is useful to treat leukoplakia, papilloma and erosion type of lichen planus.
\end{abstract}

Key words: carbon dioxide laser, leukoplakia, lichen planus

緒

\section{훔}

炭酸ガスレーザー光は，生体に照射した際，そのエネ ルギーのほとんどが，水分に吸収されるため，組織損儌 は㳭部に達しない、2)。したがって, 浅在性の表層病果部 を, defocused beam で, vaporization することは，有 刘な治療法であると考えられる。そこでわれわれは，ま ず成犬の舌に打㤝る defocused beam 照射後の組織変化 を，光顕执よび走査電顕的に観察した。ささらに，白板拝， 扁平苔解などの口腔粘膜疾患の治療に, defocused beam を用いて，若干の知見を得たので報告する。

\section{装置}

持田製蒋製 Medilaser-S 型炭酸ガスレーザーに，焦

東北大学齿学部第 1 口腔外科学教室

(主任：林 准武教授)

First Department of Oral Surgery, School of Dentistry, Tohoku University (Chief: Prof. Susumu Hayashi)

受付日：昭和59年 8 月 23 日

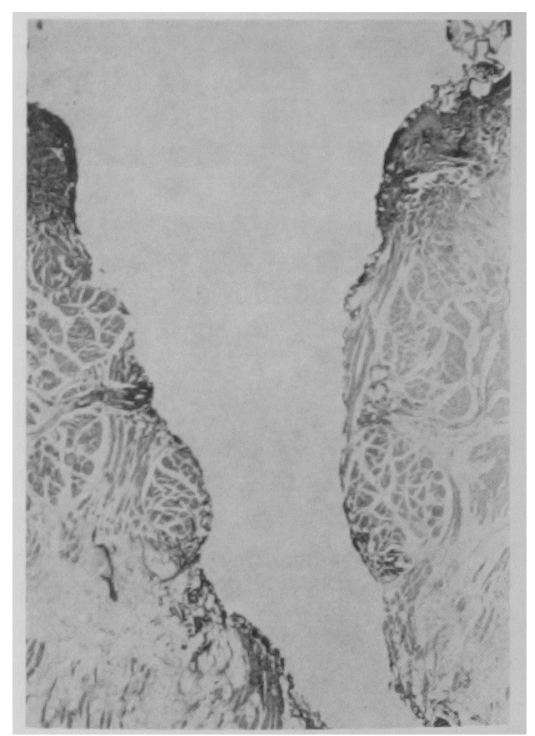

写真 1 照射直後

欠損部内側壁には，薄い孷化層と蛋白交 性層がみられる。（H-E 染色， X10） 


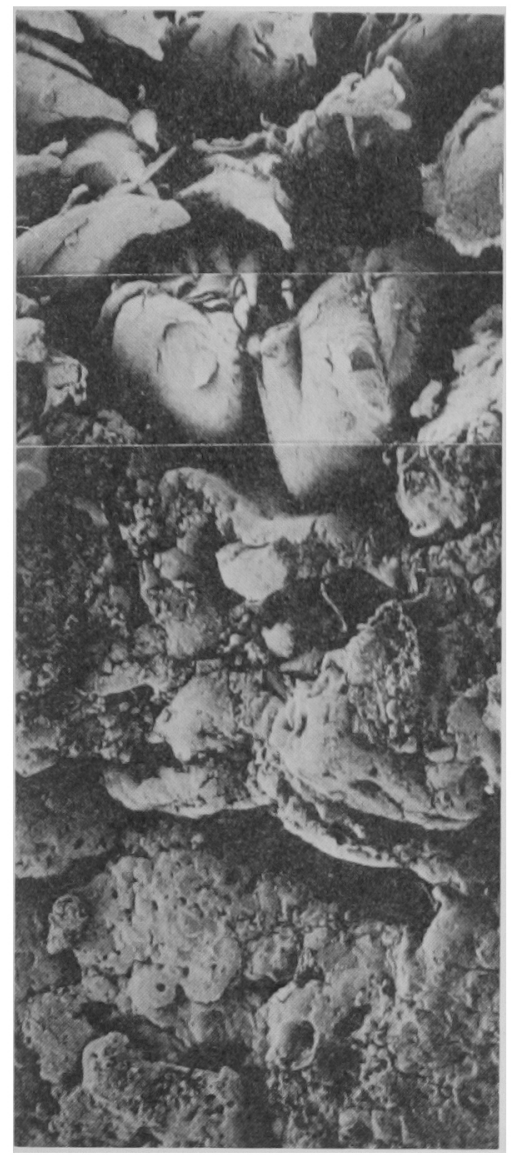

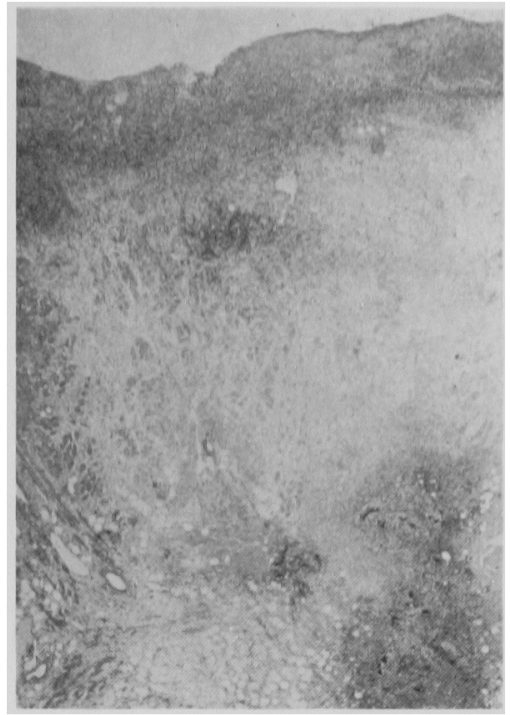

写吉 3 炤射 3 日後

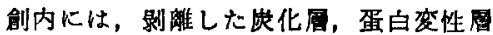
がみられる。（H-E 染色， × 10)

内側壁には，小孔がみられる。（×200）

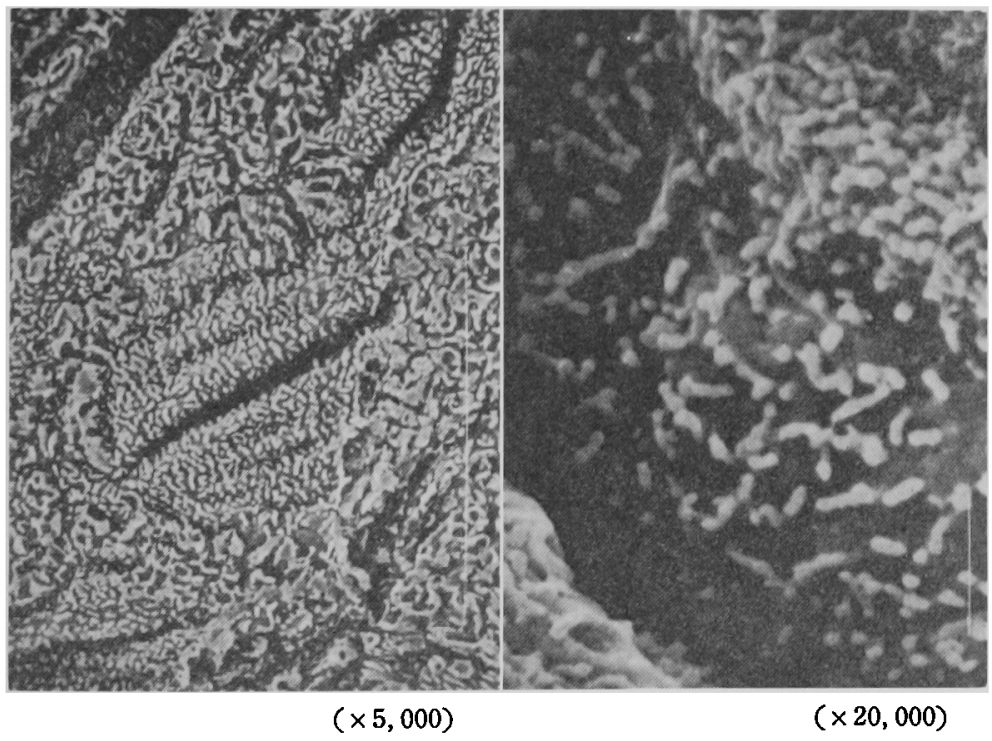

写亦 4 炤射 3 日後

上皮細胞表面に性， microvilli がみられる。 
点位直可变式ハンドピースを装崔して朋いた。

\section{defocused beam 炤射後の組䋐变化}

1) 实験材料ならびに方法

成大の㖆背朋块部に, defocused beam (spot sizc：5 $\mathrm{mm}$, 性力 $10 \mathrm{~W}$, 照射㭙間 6 秒) で, vaporization t行

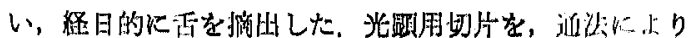

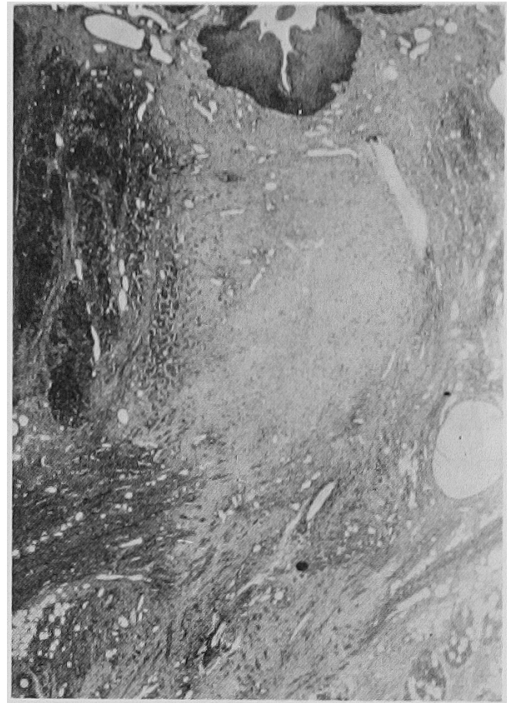

写真 5 照射 1 只後

創内は肉芽租满たされ，上皮の再生 がみられる。（H-E 染色， ×10)

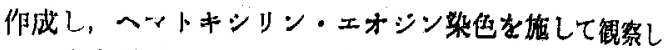

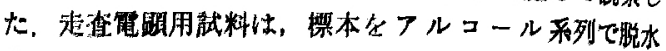

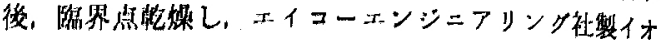

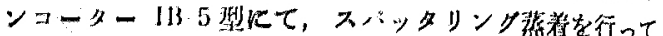

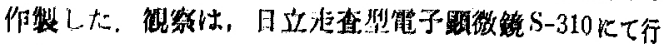
った.

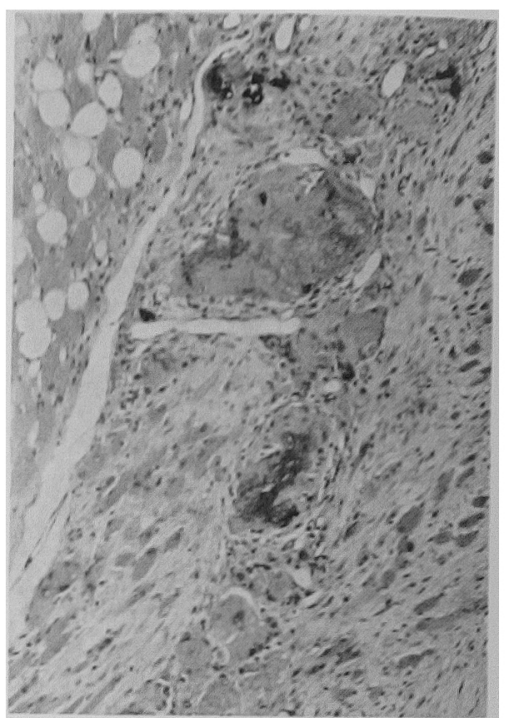

写真 6 炤射 1 只月得

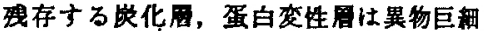
胞により処理されている。（H-E 染色， $\times 50$ )

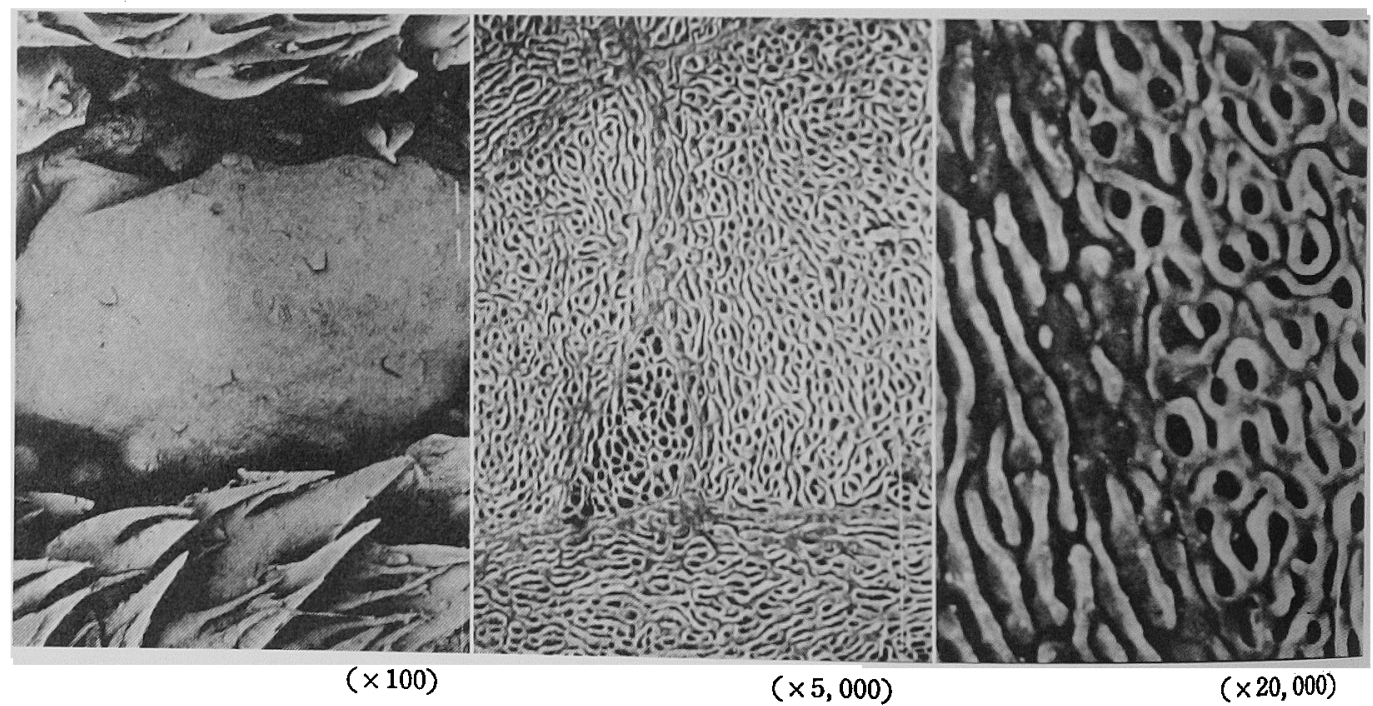

写真 7 照射 1 加月後

上皮稩胞辺緑部の比較的平行に並ふ microridge と，摆状の microridge とがみられる。 


\section{2) 耛 果}

(1)照射直後：光㩆所見；照射部には，椐状の欠挰が形 成されており，内側壁には，薄い炭化層，蛋白変性厓が 認められた，蛋白変性尿において，小血管の内腔は閉繁

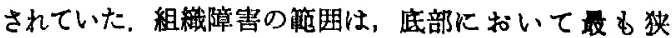
く，辺緑部にゆくに従って增大し，上皮凰で樶大となっ ていた（写索1）.

走查電影所見；欠損部周囲の上皮は，制離，整裂像を 呈し，小孔を形成していた。細胞表面の microridge は

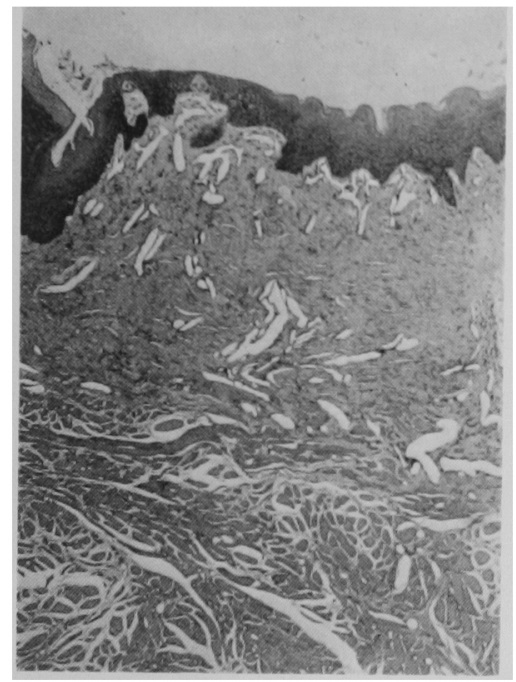

军真 8 炤射 3 只月後

瘄痕治恶が認められる。（H-E 染色， × 10)
消失し，その表面は不规则であった（写凹2）。

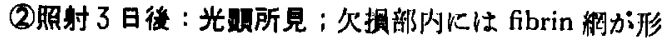

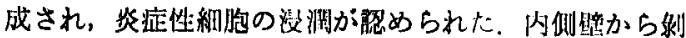

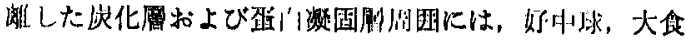

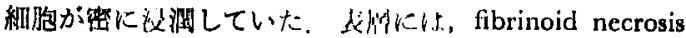
が恝められた（写西了）.

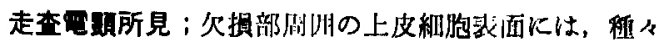
の艮さの microvilli が涊められた（写市 4).

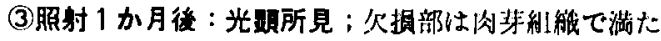

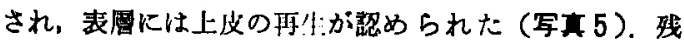

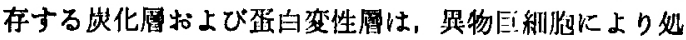
理されていた（写再6).

走查電影所見；平担な上皮細胞表面には，和胞辺悢部 の，比校的平行に並s microridge $と$ ，環状の microridge とが認められた（写真7）。

(4)炤射 3 か月後 : 光䫓所見; 欠損部性，線維性結合組 織で満たされており，疲痕治痹か認められた（写真 8).

走查電影所見；上皮細胞は㦀起しており， microridge は，環状扣上び網状構造を示していた（写真9）。

\section{口腔粘膜疾患への臨床応用}

1) 症 例

症例数は13例で，白板症 4 例，乳頭茞 1 例，扁平苔狢 8 例であった（表 $1 ， 2$ ).

\section{2) 照射方法}

出力 10 20W の defocused beam (spot size: $5 \mathrm{~mm}$ ) で，10〜30秒間照射した，病変部が広範用の場合は，数 回に分けて照射した，照射後，抗炎症性鎮痛郕と，含濑

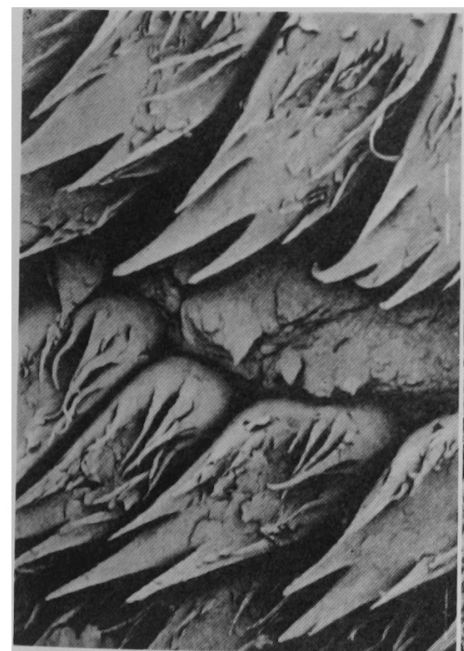

$(\times 100)$

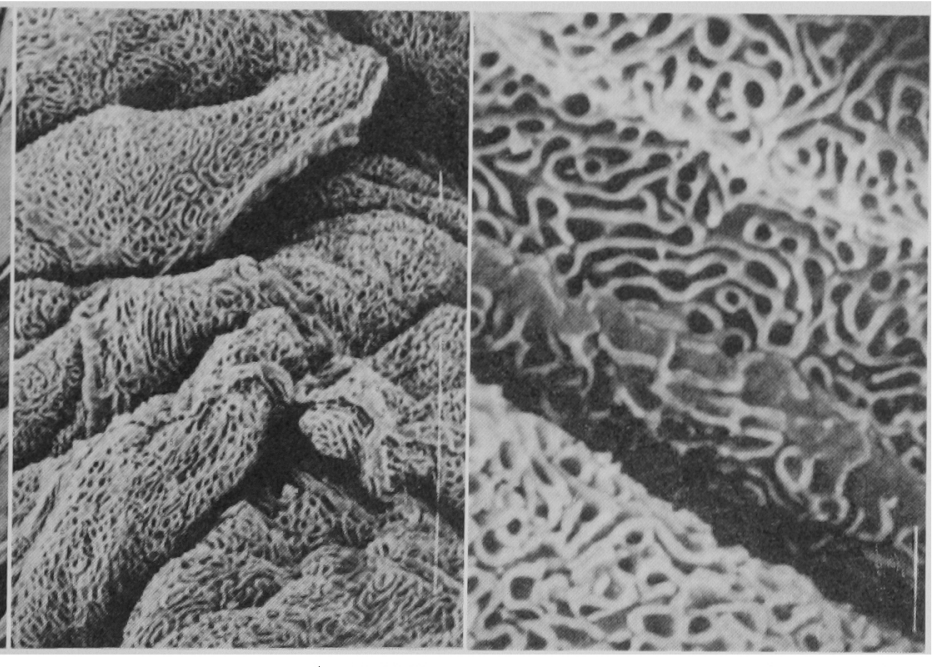

$(\times 5,000)$

写真 9 膘射 3 名月後

上皮湅胞は隆起しており摆状および網状の microridge がみられる. 
굴 1

\begin{tabular}{|c|c|c|c|c|c|c|c|}
\hline \multicolumn{6}{|c|}{ 白板娫 } & \multirow[b]{2}{*}{ 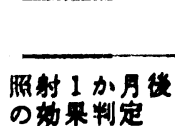 } & \multirow[b]{2}{*}{ 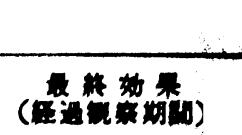 } \\
\hline $\begin{array}{l}\text { 鴜例 } \\
\text { No. }\end{array}$ & 性 & 年的 & 部 & 位。 & 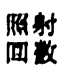 & & \\
\hline 1 & 女 & 33) & \multicolumn{2}{|c|}{ 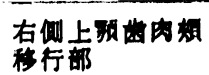 } & 1 & 真圽 & 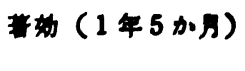 \\
\hline 2 & 女 & 56兗 & \multicolumn{2}{|c|}{ 右側口潧部 } & 1 & 璔奻 & 蕃奻（1年 5 か月） \\
\hline 3 & 明 & 51放 & \multicolumn{2}{|c|}{ 左右口角部 } & 1 & 宾奻 & 幚岈（1 年） \\
\hline 4 & 女 & 64 & \multicolumn{2}{|c|}{ 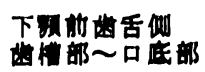 } & 1 & 算圽 & 苝炀（6 河） \\
\hline \multicolumn{8}{|c|}{ 兄颔跩 } \\
\hline 1 & 明 & 40 政 & \multicolumn{2}{|c|}{ 左側口盖邡 } & 1 & 第奻 & 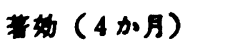 \\
\hline
\end{tabular}

表2周平苦学

\begin{tabular}{|c|c|c|c|c|c|c|c|c|c|}
\hline $\begin{array}{l}\text { 症例 } \\
\text { No. }\end{array}$ & 性 & 年踰 & 位 & 床型 & 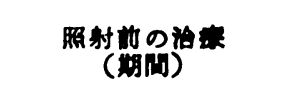 & 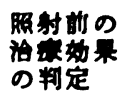 & 照雅 & 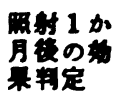 & \\
\hline 1 & 女 & 69崴 & 画側煩粘膜部 & ピラン型 & 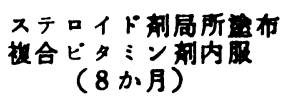 & 無 㚳 & 2 & 萧 物 & (9 加) \\
\hline 2 & 女 & 73歲 & $\begin{array}{l}\text { 右㑡煩粘樭部 } \\
\text { 右㑡舌下部 }\end{array}$ & $\begin{array}{l}\text { 䋍桨十 } \\
\text { ビラン型 }\end{array}$ & 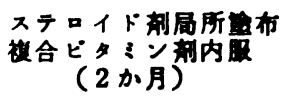 & 無 炀 & 1 & 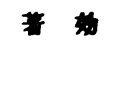 & $(8 \mathrm{~m})$ \\
\hline 3 & 男 & 42歳 & 两側煩粘膜部 & $\begin{array}{l}\text { 槅状+ } \\
\text { ビラン型 }\end{array}$ & 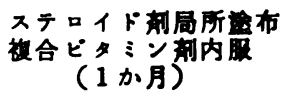 & 中有协 & 1 & 有 轰 & ( 㤫蔽) \\
\hline 4 & 女 & 39废 & 两側頓粘膜部 & 状状型 & 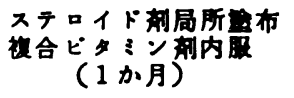 & 中有圽 & 1 & 有 姯 & 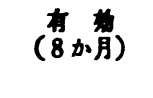 \\
\hline 5 & 女 & 63藏 & 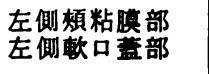 & 皃板+ & & & 4 & 有 圽 & (1年 2 加月) \\
\hline 6 & 女 & 52藏 & 両側䫅粘膜部 & $\begin{array}{l}\text { 现状+ } \\
\text { 白板型 }\end{array}$ & $\begin{array}{c}\text { ステロイト都局所睲布 } \\
\text { (3 週) }\end{array}$ & 魚 圽 & 3 & 有 协 & 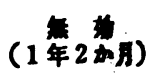 \\
\hline 7 & 女 & 42藏 & $\begin{array}{l}\text { 上下左右大曰歯 } \\
\text { 㐘槽部 }\end{array}$ & 線状型 & 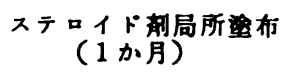 & 中有圽 & 3 & 有 协 & (1 年) \\
\hline 8 & 男 & 50墄 & $\begin{array}{l}\text { 左右煩粘䀧部 } \\
\text { 右部 }\end{array}$ & $\begin{array}{l}\text { 瓆状+ } \\
\text { 網状型 }\end{array}$ & 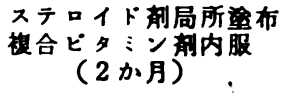 & 中有协 & 3 & 中有圽 & (1年 4 加月) \\
\hline
\end{tabular}

表 3 好果判定基望

\begin{tabular}{|c|c|}
\hline 著 & $\begin{array}{c}\text { 奻………自觉症状消失 } \\
\text { 他党症状はほ消失 }\end{array}$ \\
\hline 著 & $\begin{array}{c}\text { 奻………自覚症状消失 } \\
\text { 他党症状改善 }\end{array}$ \\
\hline & 奻………自觉㱏状改善 \\
\hline & $\begin{array}{r}\text { または, 他賞症状改善 } \\
\text { 奻…….自他賞症状の改善なし }\end{array}$ \\
\hline
\end{tabular}

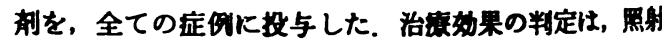

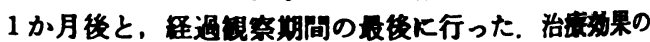
判定基準は（表了）に示した。

3) 结 果

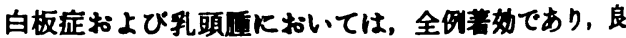

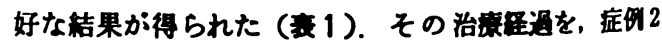
（写而10）について示すと，出力 15 W，20秒の照射て。

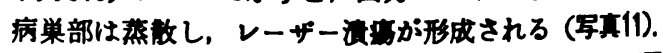
照射 1 週後頃より，照射部周囲より上皮化が進行し(写

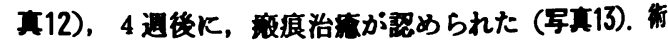
後の浮臨，出血，疼痛などは認められなかった。 


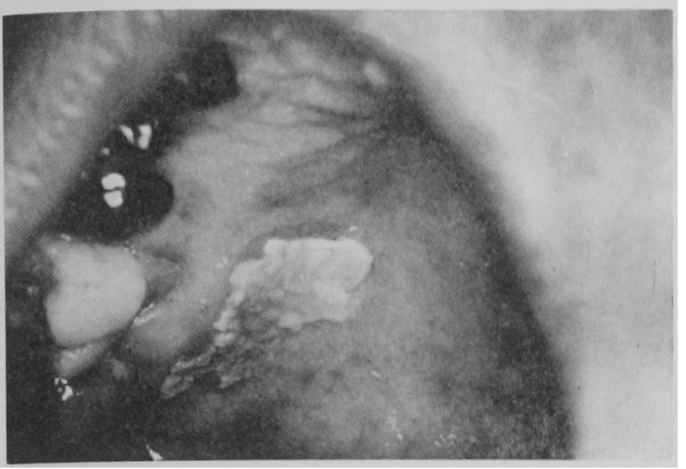

写重 10 症例 2 ：炤射前

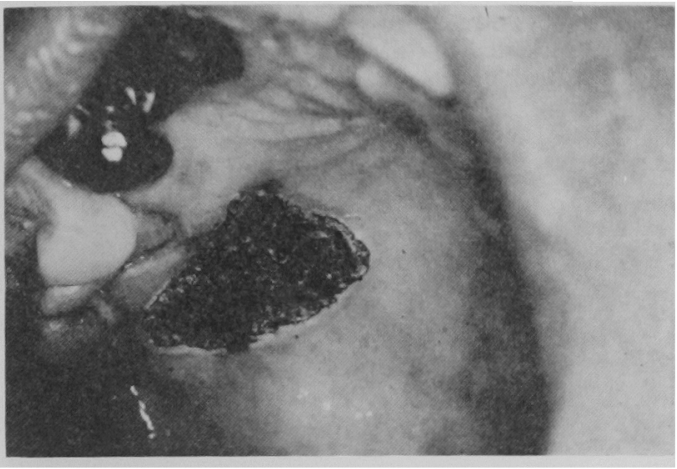

写真 11 勋囷程

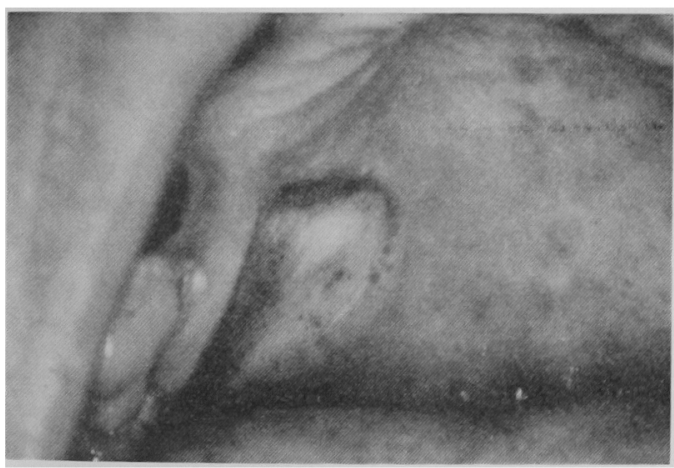

写真 12 照射 1 週後

照射部周国より上皮化が進行している。

発傾向が認められた，著效であった症例 1 （写真14）の 治療経過は，出力 $15 \mathrm{~W} ， 30$ 秒照射飞より (写真15)，1 週後頃より上皮化が進行し（写真16），4遇後には，湾 痕治瘾が認められた（写直17），照射 3 週後頃までは， 接触痛，刺激痛などが認められたが，4週後には消失し た. 照射前の試験切除標本の病理組織学的所見では，上 皮は欠落し，表層には fibrin が析出，その下層には资症 性細胞浸潤が認められた（写真18），照射 12 週後の所見

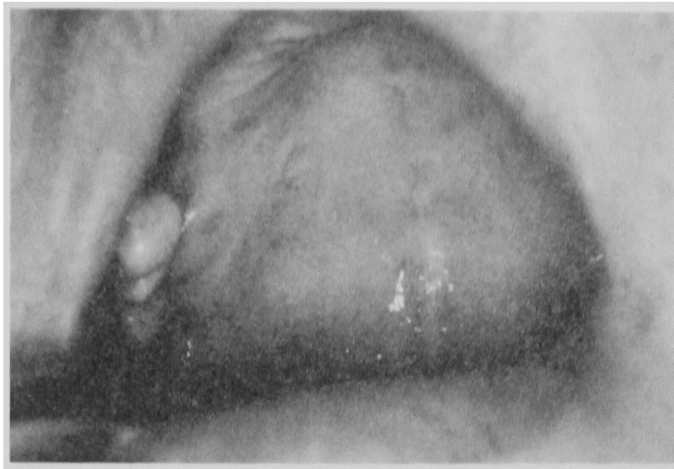

写竞 13 照射 1 か月後

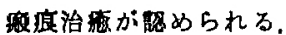

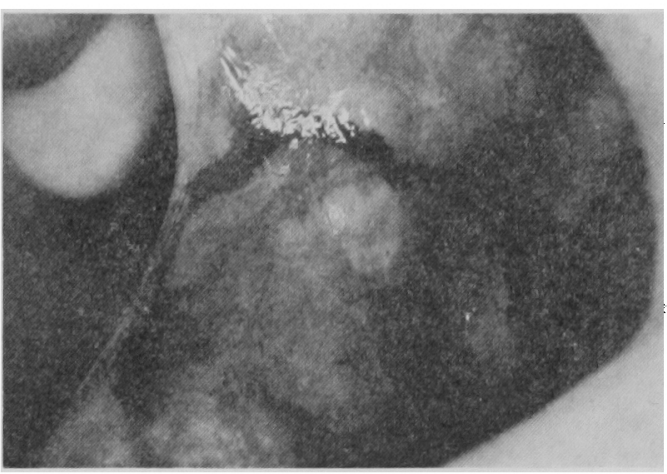

军真 14 症例 $1 ：$ 照射前

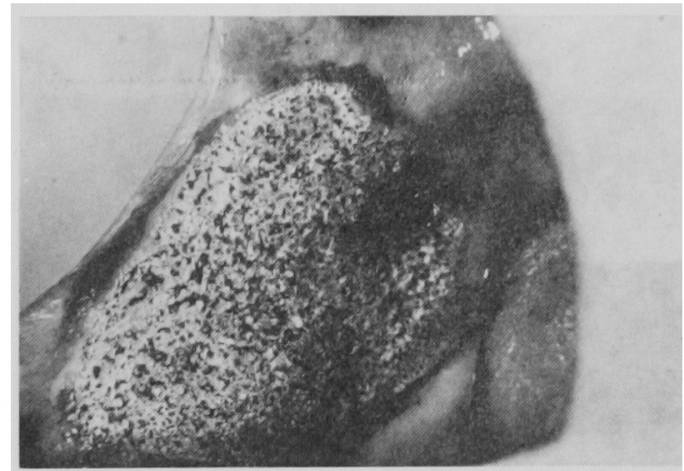

写真 15 照射直後

では, subepithelial fibrosis の像を呈しておう，上皮の 再生も認められ，扁平苔㢹の所見は認められなかった (写真19).

次に，再発傾向を示し，無効と判定した症例 8 の，照 射前の病理組織学的所見では, parakeratosis, rete ridge の消失，粘膜下層におけりるン八球の帯状浸潤などが認 められた（写直20）。哭射 6 週後では，基底細胞層の水 腫様变性, 顆粒層の出現, 粘膜下原に抢けるリン八球の 


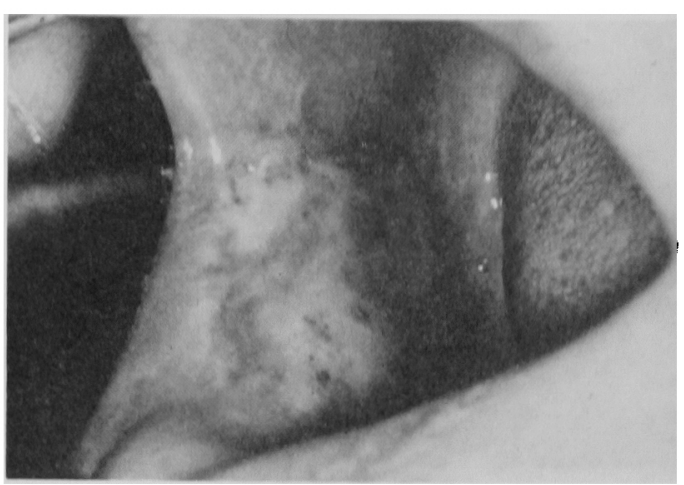

写盛 16 照射 1 週後

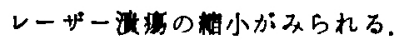

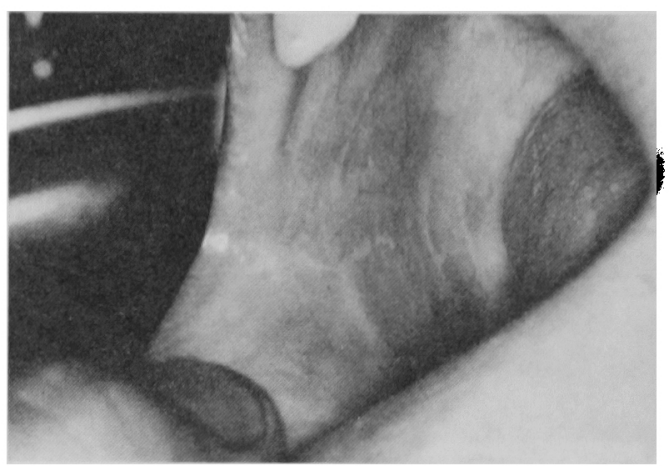

写真 17 昭籿 Iか月後

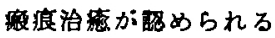

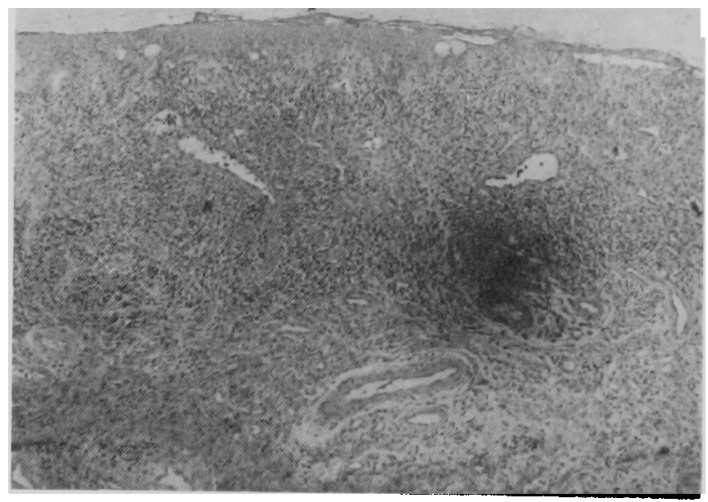

写真 18 症例 1 ：照射前

扁平苔锩のビラン型の所見が認められる。

(H-E 染色, $\times 20)$

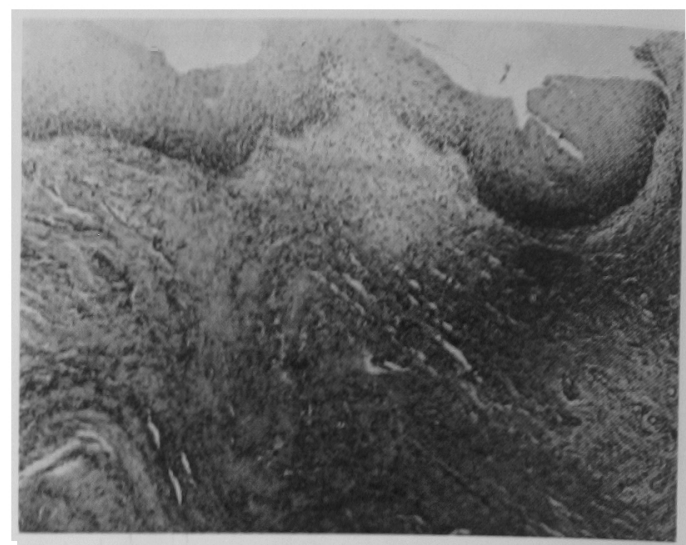

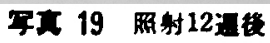

subepithelial fibrosisが幼れ，用平苦害の所見位 照められない，(H-E 染色， ×20）

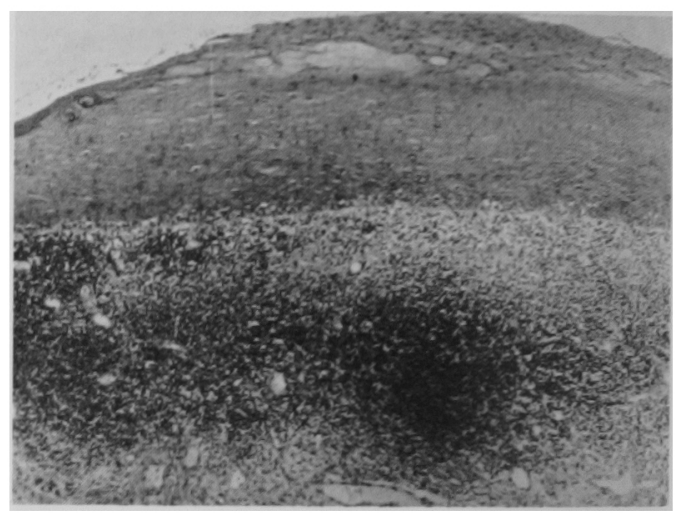

军正 20 症 8 : 照射前

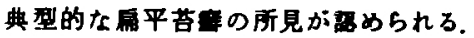

(H-E 架色, × 20)

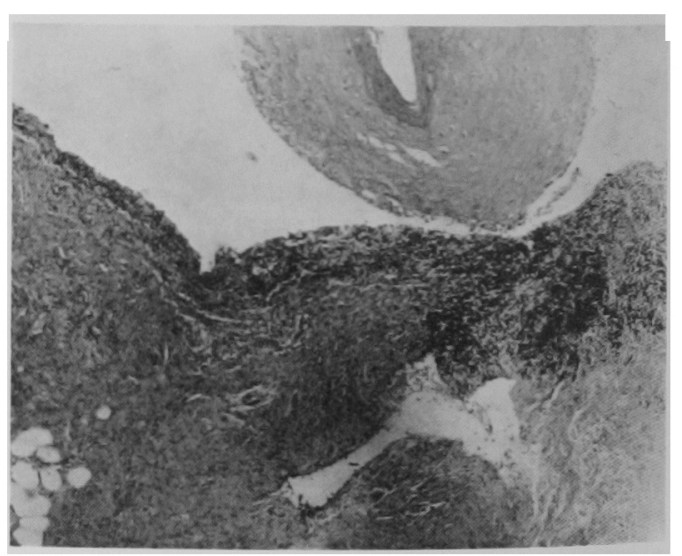

写真 21 照射 6 異镂

扁平苔暲の所見がみられその下屏には fibrosisが 認められる。（H-E 染色, $\times 20)$ 
扁平苔澴の最終効果判定では，著效 2 例，有効 3 例， 無効 3 例であった（表 2）。臨非型別では，ビラン型で 良好な結果が得られたが，環状型，線状型などでは，再 帯状浸潤，その下層の fibrosis など，絧平皆焦の所見が 認められた（写真21）。

\section{考察}

1965年に Patel によって炭酸ガスレーザーが開発され て以来，医用炭酸ガスレーザーの開発が進み，1970年代 後半より，脳外科を始めとする臨床各科で応用されるよ らになった ${ }^{3,4)}$ その特徴は，(1術中の出血，および術後 の疼痛が少ない，(2)照射時，連瘏細胞の播種，遠隔忶移 を防止できる。(3)組織の vaporization の際, その深達性 を，正確にしかも容易に調整できるなどがあげられる。

口腔外科領域に括いても，1980年頃より，臨床応用例 が報告されている5 . われわれも， vaporization によ る粘膜疾患の治療を試み，白板症，乳頭腫に捻いては， 良好な結果を得た。白板症は, 限局しているものでは, 外科的に切除するのが確実とされているが，病巣が広汎 で，かつ多部位に及ぶものでは，完全切除が不可能なこ とも少なくない8). 今回，われわれの経験した例は，比 較的限局していたが，広汎な場合でも，分割照射により 十分，効果が期待できると思われる．また，前述した炭 酸ガスレーザーの特徵を考慮すると, vaporization は, 外科的切除法よりも，優れた治療法であると考えられ る.

粘膜の扁平苔癬は，難治性であり，いまだ根治しうる 治療法も確立されていない。近年, 涷結手術や，ビタミ ンA製剤が有効であるとの報告がみられるが，その効果 は，確定的なものではない,9,10) したがって，現在の治 療法としては，ステロイド成の局所投与を主体とした治 療法が，最も広く用いられているものと思われる，今 回，われわれの経験した例では，ビラン型においては， 良好な結果が得られたものの，他の臨床型では，再発傾

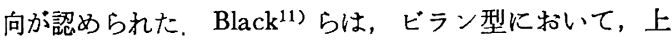
皮細胞の turn over は抑制された状態にあると報告して いる。われわれの成犬の舌を用いた実験では，レーザー 照射 3 日後より，照射部周囲の上皮細胞表面には， microvilli が認められ，1 か月後には，環状の microridge が観察された。このよらな上皮細胞の分化機構は，正常 な人の舌の, 上皮細胞表面の分化機構を観察した高木 ${ }^{12)}$ らの報告と一致する。すなわち，ビラン型においては， レーザー光の光および熱効果により，上皮細胞の turn over の抑制状態が緩和され，良好な結果が得られたの ではないかと思われる。

しかし，扁平苔㶍の成立には，細胞性免疫の関与が強 く示唆されており ${ }^{13,14)}$ ，この免疫反応を引き起こす抗原 としては，変性した上皮基底細胞や，基底板が考えられ
ている，われわれの成大の雷を用いた戈験では，憵射

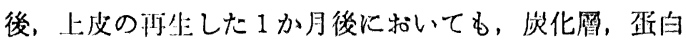
変性凰が残存していた，上皮の再生力の媹いビラン型以 外の臨床型に扣いては，これらの残存物が，抗原となる

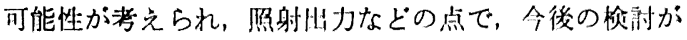
必要と思われる。

\section{結論}

われわれは，成犬の舌を用いて，vaporization 後の組 䄉変化を众即した。 さらに，白板症 4 例，乳酘腫 1 例，

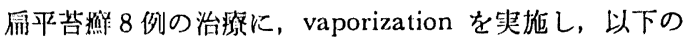
ような結椧を得た。

1）成犬の舌において，照射 1 か月後で上皮は再生 し, 残存する炭化凮扣よび蛋白变性層も 3 か月後には消 失, 瘢痕治瘳が認められた。

2) 白板症および乳頭腱に扣いては, 全例著効であり, 良好な結果が得られた。

3）扁平苔漁においては, 著効 2 例, 有効 3 例, 無効 3 例であり, 臨床型別では, ビラン型で, 良好な結果が 得られた。

本論文の要旨は, 第27回日本口腔外科学会総会（昭和 57 年10月 1 日), 第 39 回日本口腔科学会総会（昭和59年 5 月18日）に扎いて，発表した。

\section{引用 文 献}

1) 渥美和彦：レーザーの医学への応用. ME入門 講座 6. 金原出版, 東京, 1972, 251-280頁.

2) 桜井靖久：レーザーハスの現況と将来につい て. 外科治療 29: 570-578 1973.

3) Patel, C.K.N.: High power carbon dioxide lasers. Scient Am 219: 493-494 1960.

4）境澤利明：炭酸ガスレーザーメス実用機開発の 現状と将来. 医科器械学 47: 462-467 1977.

5）井田修司, 工藤泰一. 他：レーザー外科に関す る研究一口腔外科に打ける $\mathrm{CO}_{2}$ レーザーの 臨床応用—— 日口外誌 26：1214-1220 1980.

6) 岡野秀成, 橋本蜸二, 他: 口腔外科におけるレ ーザーの応用. 日本レーザー医学会誌 3：6416461982.

7）長谷川和樹, 岡部貞夫：口腔粘膜病変に対する レーザー治療 (抄). 口科誌 31：589 1982.

8) 天笠光雄, 手塚盛雄, 他: 口腔白板症の臨床型, 治療法と予後に関する研究. 日口外誌 24：2432521978.

9）中尾治郎, 森猛, 他: Lichen planus に対 する cryosurgery の臨床的研究. 日口外誌 25: 508-513 1979.

10）松浦正郎, 瀬戸晥一，他：口腔扁平苔㶍に対す る芳香族レチノイドEtretinate の治療効果. 日 
口外化 28: 537-544 1982.

11) Black, M.M., Jones, E.W., et al.: The role of the epidermis in the histopathogenesis of lichen planus. Arch Dem 105: 81-86 1972.

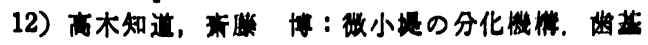
群化 18: 418-434 1976.

13) El-Labban, N.G., Kramer, I.R.H., et al. :
Light and electron-microscopic study of liquefaction degeneration in oral lichen planus. Arch Oral Biol 20: 653-657 1975.

14) Shklar, G., Evelyn, E.B.A., et al.: Basement membrane alteration in oral lichen planus. $\mathrm{J}$ Invest Dermatol 70: 45-50 1978. 